This document was prepared in conjunction with work accomplished under Contract No. DE-AC09-96SR18500 with the U. S. Department of Energy.

\title{
DISCLAIMER
}

This report was prepared as an account of work sponsored by an agency of the United States Government. Neither the United States Government nor any agency thereof, nor any of their employees, nor any of their contractors, subcontractors or their employees, makes any warranty, express or implied, or assumes any legal liability or responsibility for the accuracy, completeness, or any third party's use or the results of such use of any information, apparatus, product, or process disclosed, or represents that its use would not infringe privately owned rights. Reference herein to any specific commercial product, process, or service by trade name, trademark, manufacturer, or otherwise, does not necessarily constitute or imply its endorsement, recommendation, or favoring by the United States Government or any agency thereof or its contractors or subcontractors. The views and opinions of authors expressed herein do not necessarily state or reflect those of the United States Government or any agency thereof. 
WSRC-TR-2005-00577, Rev. 0

Keywords: Waste processing, solvent extraction, liquid waste, MCU

Retention: Permanent

\title{
MCU MATERIALS COMPATIBILITY WITH CSSX SOLVENT
}

\author{
F. F. Fondeur \\ T. B. Peters \\ D. D. Walker \\ T. L. White
}

January 13, 2006

Washington Savannah River Company Savannah River Site

Aiken, SC 29808

Prepared for the U.S. Department of Energy Under Contract Number DE-AC09-96SR18500

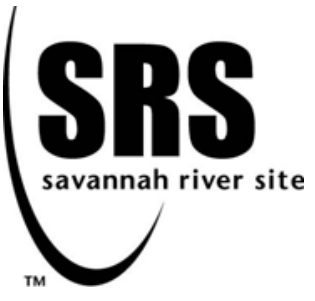


WSRC-TR-2005-00577, Rev. 0

REVIEWS AND APPROVALS

Authors:

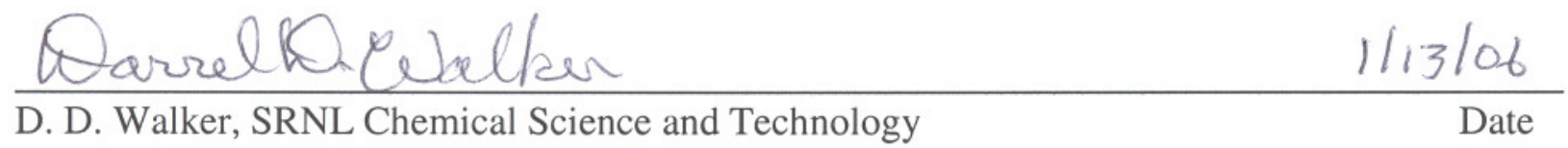

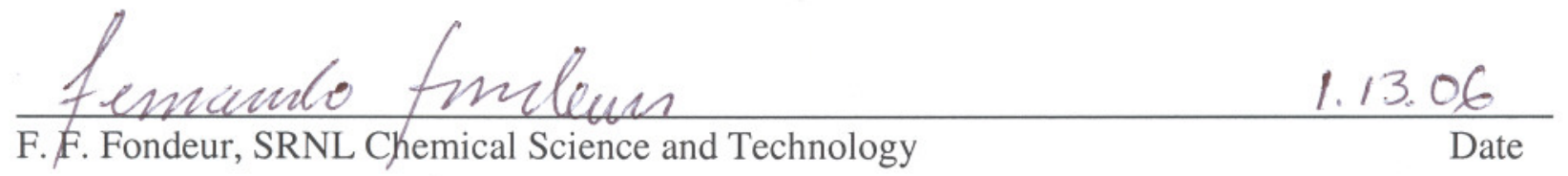

\begin{tabular}{lr} 
Thomas B. Peters & $1-13-2006$ \\
\hline T. B. Peters, SRNL Chemical Science and Technology & Date
\end{tabular}

$\frac{1 / 13 / 06}{\text { Date }}$

Technical Reviewer:

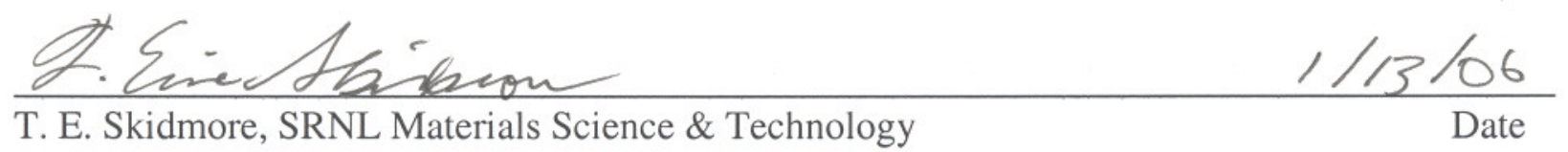

SRNL Management:

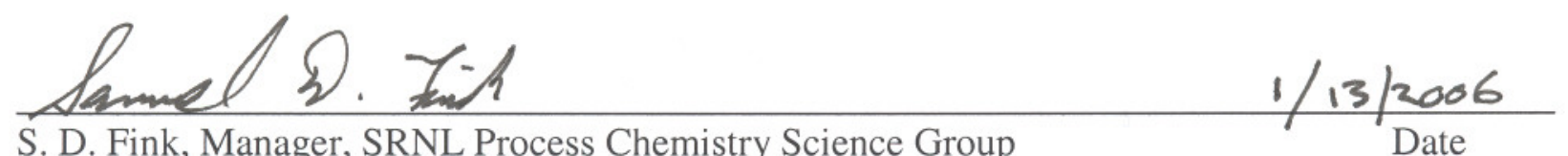

S. D. Fink, Manager, SRNL Process Chemistry Science Group

Date

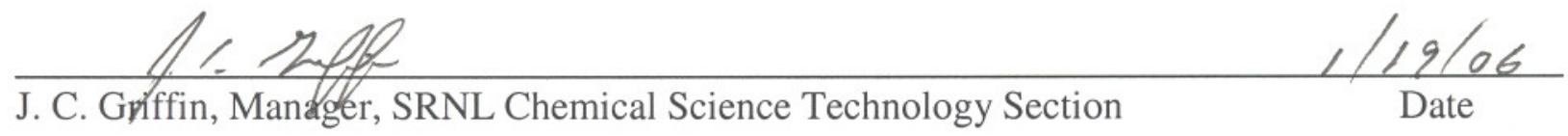

Customer:

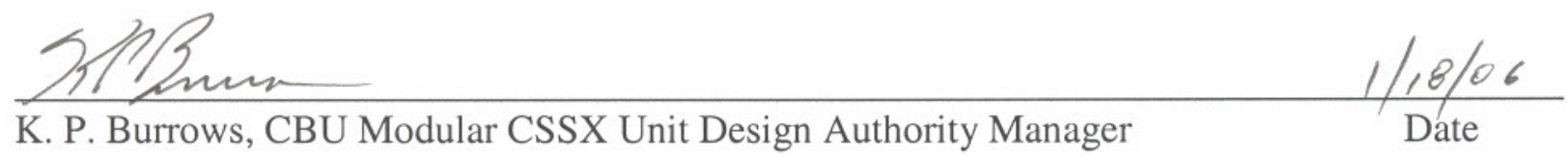

Page 2 of 8 
WSRC-TR-2005-00577, Rev. 0

\section{MCU MATERIALS COMPATIBILITY WITH CSSX SOLVENT}

\section{Summary}

The Modular Caustic-Side Solvent Extraction (CSSX) Unit (MCU) plans to use several new materials of construction not previously used with CSSX solvent. SRNL researchers tested seven materials proposed for service in seal and gasket applications. None of the materials leached detectable amounts of components into the CSSX solvent during 96 hour tests. All are judged acceptable for use based on their effect on the solvent. However, some of the materials adsorbed solvent or changed dimensions during contact with solvent. Consultation with component and material vendors with regard to performance impact and in-use testing of the materials is recommended.

Polyetheretherketone (PEEK), a material selected for use in contactor bearing seals, did not gain weight or change dimensions on contact with CSSX solvent. Analysis of the solvent contacted with this material showed no impurities and the standard dispersion test gave acceptable phase separation results. The material contains a leachable hydrocarbon substance, detectable on exposed surfaces, that did not adversely contaminate the solvent within the limits of the testing. We recommend contacting the vendor to determine the source and purpose of this component, or, alternatively, pursue the infrared analysis of the PEEK in an effort to better define potential impacts.

\section{Experimental}

\section{Samples}

MCU Design Authority personnel obtained samples of seven materials of construction planned for use in the MCU. Table 1 provides identification information and a description of the samples. In some cases (i.e., ETFE, Grafoil ${ }^{\circledR}$ stem seal and bonnet gasket) an entire piece was leached. In other cases, the samples provided were cut in half (i.e., Simriz ${ }^{\circledR}$, Grafoil ${ }^{\circledR}$ Grade GTB) or a piece was cut off (i.e., PEEK). The gasket construction includes concentric rings of GTA nuclear grade graphite held together with metal bands. When cut into pieces small enough for leaching, the graphite and metal bands separated. The two portions were leached separately.

\section{Leach Test}

In the general procedure, pieces of the materials were soaked, without agitation, in CSSX solvent for $96 \pm 1$ hours at ambient temperature $\left(23 \pm 3^{\circ} \mathrm{C}\right)$. Individual tests used $\sim 40 \mathrm{~mL}$ of CSSX solvent (archive sample of batch prepared at SRNL, Batch\#S2-D1-Yes-BOB-T-WI). ${ }^{1,2}$ Table 2 lists the solvent composition. Testing of the Simriz ${ }^{\circledR}$ sample varied from the others. The small size of the Simriz ${ }^{\circledR}$ O-ring necessitated smaller test volumes ( $\sim 15 \mathrm{~mL}$ of solvent). In addition, Simriz ${ }^{\circledR}$ pieces were slowly tumbled in a mixture of solvent and an aqueous phase (either $0.05 \mathrm{M}$ nitric acid or simulated waste solution) to more closely simulate the service application. Table 3 lists the composition of the simulated waste solution. ${ }^{3}$ The simplified simulated waste did not contain hazardous, transition metal, or organic components. 
TABLE 1. Identification Information for Samples

\begin{tabular}{|c|c|c|c|c|c|}
\hline & Material & Source & Application & Shape & Other \\
\hline 1 & $\begin{array}{l}\text { ETFE }\left(\text { Tefzel }^{\circledR} \text { ) }\right. \\
\text { (ethylene- } \\
\text { tetrafluoroethylene } \\
\text { copolymer) }\end{array}$ & McCanna & Valve seat & ring, $4 \mathrm{~cm}$ diam & Color: white \\
\hline 2 & $\begin{array}{l}\text { Grafoil }^{\circledR} \\
\text { (flexible graphite) }\end{array}$ & McCanna & stem seal & ring, $2 \mathrm{~cm}$ diam & $\begin{array}{l}\text { Color: black, metallic } \\
\text { sheen }\end{array}$ \\
\hline 3 & Grafoil $^{\circledR}$ & McCanna & bonnet gasket & ring, $5 \mathrm{~cm}$ diam & $\begin{array}{l}\text { Color: black, metallic } \\
\text { sheen }\end{array}$ \\
\hline 4 & $\begin{array}{l}\text { Graphite (GTA } \\
\text { nuclear grade) from } \\
\text { Garlock Edge }{ }^{\mathrm{TM}} \text { flex } \\
\text { seal gasket }\end{array}$ & Garlock & $\begin{array}{l}\text { piping flange } \\
\text { gasket }\end{array}$ & ring, $13 \mathrm{~cm}$ diam & $\begin{array}{l}\text { composed of } \\
\text { alternating rings of } \\
\text { graphite and 304L } \\
\text { stainless steel bands }\end{array}$ \\
\hline 5 & $\begin{array}{l}\text { Grafoil }^{\circledR} \\
\text { Grade GTB }\end{array}$ & & & sheets & $\begin{array}{l}\text { Color: black, metallic } \\
\text { sheen }\end{array}$ \\
\hline 6 & Simriz $^{\circledR}$ & & bearing seal & ring, & \\
\hline 7 & $\begin{array}{l}\text { PEEK } \\
\text { (polyetheretherketone) }\end{array}$ & & & $\begin{array}{l}\text { disk, } 18 \mathrm{~cm} \text { diam } \\
\text { x } 2.5 \mathrm{~cm} \text { thick }\end{array}$ & Color: light gray \\
\hline
\end{tabular}

TABLE 2. CSSX Solvent Composition ${ }^{2}$

\begin{tabular}{|l|l|}
\hline Component & $\begin{array}{l}\text { Concentration } \\
\text { (molar) }\end{array}$ \\
\hline Extractant & 0.007 \\
\hline Modifier & 0.75 \\
\hline TOA & 0.003 \\
\hline Isopar $^{\circledR} \mathrm{L}$ & (remainder) \\
\hline
\end{tabular}

TABLE 3. Simulated Waste Solution

\begin{tabular}{|l|l|l|l|l|}
\hline Component & $\begin{array}{l}\text { Concentration } \\
\text { (molar) }\end{array}$ & Component & $\begin{array}{c}\text { Concentration } \\
\text { (molar) }\end{array}$ \\
\hline $\mathrm{Na}^{+}$ & 5.6 & & $\mathrm{CO}_{3}{ }^{2-}$ & 0.15 \\
\hline $\mathrm{K}^{+}$ & 0.015 & & $\mathrm{Cl}^{-}$ & 0.024 \\
\hline $\mathrm{Cs}^{+}$ & 0.00014 & & $\mathrm{~F}^{-}$ & 0.028 \\
\hline $\mathrm{OH}^{-}$ & 2.06 & & $\mathrm{PO}_{4}{ }^{3-}$ & 0.007 \\
\hline $\mathrm{NO}_{3}{ }^{-}$ & 2.03 & & oxalate $^{-}$ & 0.008 \\
\hline $\mathrm{NO}_{2}{ }^{-}$ & 0.50 & $\mathrm{SiO}_{3}{ }^{2-}$ & 0.03 \\
\hline $\mathrm{AlO}_{2}{ }^{-}$ & 0.28 & & $\mathrm{MoO}_{4}{ }^{2-}$ & 0.00007 \\
\hline $\mathrm{SO}_{4}{ }^{2-}$ & 0.14 & \multicolumn{2}{|l}{} \\
\cline { 2 - 3 }
\end{tabular}




\section{Examination Methods}

Personnel evaluated the solvent and materials using infrared (IR) spectroscopic analysis, including IR and Raman spectra of the solvent before and after contact with the materials, and surface IR spectra of the materials before and after contact with solvent. Researchers also measured weight and dimensional changes in the materials samples, and recorded visual observations (such as color changes, sample integrity, and solvent transparency).

\section{Dispersion Test Protocol}

Using a literature procedure, ${ }^{4}$ SRNL researchers performed dispersion tests on combinations of the solvent and simulated waste solution. The tests used graduated cylinders (of 100-mL working volume) with ground glass joints or Teflon ${ }^{\mathrm{TM}}$ cap plugs. The cylinders were physically similar, approximately $190 \mathrm{~mm}$ tall and $25.4 \mathrm{~mm}$ diameter. Researchers measured break times ( $\mathrm{t}_{\mathrm{b}}$, seconds) with a calibrated stopwatch and calculated the dispersion number $\left(\mathbf{N}_{\mathbf{D I}}\right)$ using the following equation where $\mathbf{H}$ is the working height of the graduated cylinder in meters.

$$
\mathrm{N}_{\mathrm{DI}}=\frac{1}{\mathrm{t}_{\mathrm{b}}} \sqrt{\frac{\mathrm{H}}{9.81}} \quad \text { Equation } 1
$$

The literature procedure indicates that replicate results may vary up to $25 \%$, so we take this value as the experimental uncertainty.

\section{Results}

Table 4 summarizes the results of the effects of the materials on the solvent properties. Table 5 summarizes results of the effects of the solvent on the materials samples.

\section{Effects on Solvent}

None of the materials imparted color to the solvent or caused the solvent to become hazy. IR analysis detected no impurities in the solvent samples after leaching. Some changes exceeding the nominal error ( $\pm 25 \%)$ occurred in the dispersion numbers. For most materials, (i.e., ETFE, GTA graphite, Grafoil ${ }^{\circledR}$, and PEEK), the dispersion number increased relative to the controls. An increase in the dispersion number indicates improved separation and is of benefit to the MCU process. Simriz ${ }^{\circledR}$ caused a decrease in the dispersion number relative to the control. However, the decrease to a value of 0.0005 remains within the range considered acceptable for the process (acceptable: $>0.0004){ }^{5}$ Note that the Simriz ${ }^{\circledR}$ measurements were made using smaller apparatus that may have affected the accuracy of the measurement. Nevertheless, we report the results since the control samples in the small apparatus agreed well with other controls.

The metal bands from the Garlock gasket also reduced the dispersion number. Again, the reduction did not cause the dispersion number to drop below the acceptable value. However, it is not clear why the metal parts caused the change. Researchers noted that the bands contained periodic yellow spots, possibly paint or glue, that did not change in appearance during leaching. 
WSRC-TR-2005-00577, Rev. 0

TABLE 4. Effects of Materials on CSSX Solvent

\begin{tabular}{|c|c|c|c|c|c|}
\hline Material & $\begin{array}{l}\text { Solvent } \\
\text { Color }\end{array}$ & $\begin{array}{l}\text { Solvent } \\
\text { Clarity }\end{array}$ & IR Analysis & \multicolumn{2}{|c|}{$\begin{array}{c}\text { Dispersion Number } \\
\text { (acceptable range: } \\
>0.0004) \\
\end{array}$} \\
\hline ETFE $\left(\right.$ Tefzel $\left.^{\circledR}\right)$ & No change & No change & No detectable impurities & & 0.0013 \\
\hline $\begin{array}{l}\text { GTA graphite from } \\
\text { Garlock gasket }\end{array}$ & No change & No change & No detectable impurities & $\begin{array}{l}\text { Graphite } \\
\text { Metal rings }\end{array}$ & $\begin{array}{l}0.0012 \\
0.0006\end{array}$ \\
\hline Grafoil $^{\circledR}$ stem seal & No change & No change & No detectable impurities & & 0.0015 \\
\hline $\begin{array}{l}\text { Grafoil }^{\circledR} \text { bonnet } \\
\text { gasket }\end{array}$ & No change & No change & No detectable impurities & & 0.0012 \\
\hline Grafoil $^{\circledR}$ Grade GTB & No change & No change & No detectable impurities & & 0.0014 \\
\hline Simriz $^{\circledR}$ & No change & No change & No detectable impurities & $\begin{array}{l}\text { Strip } \\
\text { Waste }\end{array}$ & $\begin{array}{l}0.0005 \\
0.0005\end{array}$ \\
\hline PEEK & No change & No change & No detectable impurities & & 0.0014 \\
\hline Controls & & & & $\begin{array}{r}\text { Large appar } \\
0.001 \\
\text { Small appar } \\
0.001\end{array}$ & $\begin{array}{l}\text { tus } \\
\pm 0.0002 \\
\text { tus } \\
\pm 0.0001\end{array}$ \\
\hline
\end{tabular}

TABLE 5. Effects of CSSX Solvent on Materials

\begin{tabular}{|c|c|c|c|c|}
\hline Material & Color/Integrity & $\begin{array}{c}\text { Weight } \\
(\%)\end{array}$ & Dimensions & $\begin{array}{c}\text { Surface IR } \\
\text { Analysis* }\end{array}$ \\
\hline ETFE $\left(\right.$ Tefzel $^{\circledR}$ ) & No change & +0.2 & $\begin{array}{ll}\text { ID } & -3 \% \\
\text { OD } & +0.01 \% \\
\text { Thickness } & -4 \% \\
\end{array}$ & NA \\
\hline $\begin{array}{l}\text { GTA graphite from } \\
\text { Garlock Gasket }\end{array}$ & No change & +28 & Thickness +33\% & NA \\
\hline Grafoil $^{\circledR}$ stem seal & No change & +38 & Thickness +39\% & NA \\
\hline $\begin{array}{l}\text { Grafoil }^{\circledR} \text { bonnet } \\
\text { gasket }\end{array}$ & No change & +39 & Thickness +60\% & NA \\
\hline $\begin{array}{l}\text { Grafoil }^{\circledR} \text { Grade } \\
\text { GTB }\end{array}$ & No change & +46 & No change & NA \\
\hline Simriz $^{\circledR}$ & No change & +0.08 & Thickness $+2 \%$ & $\begin{array}{l}\text { Surface } \\
\text { hydrocarbon } \\
\text { removed }\end{array}$ \\
\hline PEEK & No change & +0.01 & No change & $\begin{array}{l}\text { Surface } \\
\text { hydrocarbon } \\
\text { partially removed }\end{array}$ \\
\hline
\end{tabular}




\section{Effects on Samples}

Visual examination of the samples showed no changes due to contact with CSSX solvent. Samples maintained their integrity (i.e., did not break down into smaller pieces) and did not change color.

All of the samples showed weight gains. The magnitude of the weight gain $(0.01 \%)$ for PEEK approximately equaled the error in the weight measurement, and we consider it insignificant. The weight gains for Simriz ${ }^{\circledR}$ and ETFE (Tefzel ${ }^{\circledR}$ ) exceeded the measurement errors but are quite small. Weight gains by the GTA graphite (Garlock gasket) and Grafoil ${ }^{\circledR}$ samples proved quite large (28 to 46\%). In three cases (GTA graphite, Grafoil ${ }^{\circledR}$ stem seal, and Grafoil ${ }^{\circledR}$ bonnet gasket), researchers noted bubbles of gas evolved over several hours following immersion of the material in CSSX solvent. We suspect the materials are porous and the air bubbles result from displacement of air by the solvent. The large weight gains support this interpretation.

The dimensional changes in the samples follow a pattern similar to the weight changes. PEEK showed no change in dimensions, commensurate with the lack of weight gain. Simriz ${ }^{\circledR}$ measured slightly larger (+2\%) in both tests (in $0.05 \mathrm{M}$ nitric acid and in simulated waste solution). ETFE $\left(\right.$ Tefzel $^{\circledR}$ ) unexpectedly measured slightly smaller in two dimensions, although the outside diameter of the O-ring remained constant. The shrinkage in the inside diameter and thickness may reflect measurement uncertainty. The GTA graphite (Garlock gasket), Grafoil ${ }^{\circledR}$ stem seal, and Grafoil ${ }^{\circledR}$ bonnet gasket increased significantly in thickness, reflecting similar changes in weight. The Grafoil ${ }^{\circledR}$ Grade GTB sheet did not measurably increase in thickness, even though it did gain considerably in weight. We recommend evaluating the potential impact on performance of these changes in size and weight. Though often of limited value for specific applications, vendor data (Union Carbide) indicates high compatibility of homogeneous Grafoil ${ }^{\circledR}$ sheet with many hydrocarbons, including kerosene. ${ }^{6}$

The surface IR analysis of the Simriz ${ }^{\circledR}$ and PEEK materials showed CSSX solvent removed hydrocarbons present on the original surfaces. The material removed from the Simriz ${ }^{\circledR}$ may have been oils imparted to the surface during human handling. The PEEK material, however, appear to contain a hydrocarbon on freshly prepared surfaces that were not contaminated during sample preparation. This material was partially removed during the leach test.

\section{Conclusions}

None of the materials tested imparted detectable amounts of impurities to the solvent, as evidenced by no visible color changes, no haziness, and no detectable compounds in the IR spectroscopy. These materials will be used sparingly in the MCU process, so the potential for solvent contamination is small just from consideration of the volume of solvent in contact with the limited volume of the materials. Some changes in dispersion number occurred but measured values remain within acceptable limits. From the point of view of impact on solvent, all of the materials are considered acceptable in MCU service. 
The results are not as clear from the point of view of the impact of the solvent on the materials. PEEK, Simriz ${ }^{\circledR}$, and ETFE (Tefzel ${ }^{\circledR}$ ) showed the least effects. Weight gains and dimensional changes were non-existent or quite small. However, the GTA graphite and Grafoil ${ }^{\circledR}$ products gained significantly in weight, with corresponding changes in dimensions (with the exception of Grafoil $^{\circledR}$ Grade GTB sheet). Depending on the application, these changes may be acceptable if cracking, softening, stress-relaxation, binding or other forms of degradation that may occur do not cause component failure. Consultation with component and material vendors with regard to performance impact and in-use testing of these materials is recommended.

\section{References}

${ }^{1}$ K. Adu-Wusu, D. D. Walker, T. L. White, and S. L. Crump, memorandum to S. D. Fink, "Preparation of Caustic-Side Solvent Extraction (CSSX) Solvent with BOBCalixC6 for Wright Industries - Component Amounts, Analytical and Quality Assurance Results," SRNL-WPT2005-00134, December 2, 2005.

2 Systematic names for solvent components are: modifier, 1-(2,2,3,3-tetrafluoropropoxy)-3-(4sec-butylphenoxy)-2-propanol (CS-7SB); extractant, calix[4]arene-bis(tert-octylbenzo-crown-6) (BOBCalixC6); and TOA, tri-n-octyl amine.

${ }^{3}$ R. A. Peterson, "Preparation of Simulated Waste Solutions for Solvent Extraction Testing," WSRC-RP-2000-00361, Rev. 0, May 1, 2000.

${ }^{4}$ R. A. Leonard, “Solvent Characterization Using the Dispersion Number”, Separation Science and Technology, 30(7-9), pg. 1103-1122, 1995.

${ }^{5}$ L. N. Klatt, J. F. Birdwell, P. V. Bonnesen, L. H. Delmau, L. J. Foote, D. D. Lee, R. A.Leonard, T. G. Levitskaia, M. P. Maskarinec, and B. A. Moyer, "Caustic-Side Solvent Extraction Solvent - Composition Recommendation," ORNL/TM-2001/258.

${ }^{6}$ Union Carbide Grafoil ${ }^{\circledR}$ Engineering Design Manual, Volume 1, 1987.

CC:

K. Adu-Wusu, 773-41A

C. I. Aponte, 730-1B

D. A. Boyce, 730-1B

K. P. Burrows, 730-1B

E. A. Brass, 730-1B

S. J. Brown, 730-1B

S. D. Fink, 773-A

M. W. Geeting, 730-1B

A. P. Giordano, 730-1B

M. R. Gober, 730-1B
J. C. Griffin, 773-A

W. L. Isom, Jr., 766-H

J. E. Marra, 773-A

F. F. Fondeur, 773-A

W. E. Narrows, 730-1B

C. A. Nash, 773-42A

T. B. Peters, 773-42A

M. R. Poirier, 773-42A

T. E. Skidmore, 730-A

D. D. Walker, 773-A 